\title{
Bionomics and Management of Onion Thrips Thrips tabaci (Lindeman) on Onion Grown under Kashmir Conditions
}

\author{
Asma Sherwani ${ }^{1}$, Peerzada Shafat Hussian ${ }^{2}$, Malik Mukhtar ${ }^{2} *$ and Shaheen Gul $^{3}$ \\ ${ }^{1}$ Division of Entomology Faculty of Horticulture SKUAST Kashmir, India \\ ${ }^{2}$ Krishi Vigyan Kendra Bandipora SKUAST Kashmir, India \\ ${ }^{3}$ Mountain Research Centre for Field Crops SKUAST Kashmir, India \\ *Corresponding author
}

Keywords

Onion, Thrips,

Seasonal incidence,

Bionomics

Article Info

Accepted:

20 January 2020

Available Online:

10 February 2020

\section{A B S T R A C T}

The present investigation was conducted to study the seasonal incidence of thrips, Thrips tabaci on onion at various locations in Kashmir valley, during the year 2017-18 and management of thrips during the year 2019 . Onion crop was raised as per the recommended package of practices. The crop was observed on weekly basis to find out the incidence of onion thrips. The infestation of thrips was first observed from $1^{\text {st }}$ week of May to $4^{\text {th }}$ week of July. The percent incidence and severity index ranged from 6.66 and 1.07 and 30.0 and 1.60 from May to July respectively at Shalimar. Likewise the percent incidence and severity index ranged from 10.50 and 1.20 and 30.55 and 1.49 from May to July respectively at Tailbal. Similarly at Zakura the percent incidence and severity index ranged from 6.67 and 1.11 and 25.0 and 1.48 from May to July respectively. Thiacloprid 21.7 SC @ $0.4 \mathrm{ml} /$ litre of water proved efficacious for the management of onion thrips at both the locations of Shalimar and Mirgund with average percent mortality of 74.05 and 73.49 respectively.

\section{Introduction}

Onion (Allium cepa Linn) belongs to family Alliaceae is one of the most important vegetable cum condiment crop grown throughout the world. Onion is one of the unique vegetables that are used throughout the year in the form of salad or condiments or for cooking with other vegetables. Onion bulbs have many medicinal properties and have been used as medicine for many centuries. Onion crop is infested by many insect pests like thrips, Thrips tabaci (Lindeman); maggot fly, Delia antigua (Meigen); caliothrips, Caliothrips indicus (Bangall) and tobacco caterpillar, Spodoptera litura (Fabricius) are 
considered the major limiting factors for higher production of good quality onion bulbs as well as seeds. Among the various pests, thrips, Thrips tabaci is a regular and potential pest of onion causes considerable huge losses in quality and yield (Dharmasena, 1998). Therefore management of onion thrips is of vital importance to the production and profitability of this crop.

If onion thrips are not controlled, damage can routinely reduce bulbs yield by 30 to 50 per cent (Nault and Shelton, 2010) and onion yield reductions can reach up to the levels from 34 to 50 per cent (Fournier et al., 1995). Thrips attack on onion is observed at all stages of crop growth, but their count increases from bulb initiation and remain high up to the bulb development till maturity of the crop. Thrips are the major problem on this crop and the most common during warm weather. Thrips are very small, slender insect pest seen with a hand lens. They feed with a rasping and sucking mouthparts that removes leaf chlorophyll causing white to silver patches and streaks. Thrips in onion are difficult to control because of succulent nature of leaves (Shitole et al., 2002). Therefore to combat the insect pests, farmers are solely dependent on chemical pesticides. Onion grower typically apply insecticides regularly on weekly basis, resulting in 9-12 insecticide applications per crop season irrespective of knowing the time and incidence of this pest at right time and manner. Hence keeping the importance of this insect pest in mind the present study with regard to bionomics and management seems to be highly effective in creating awareness in farmers' community for containing this pest on onion.

\section{Materials and Methods}

Field experiments were conducted from seedling stage till harvest of the crop on various locations of Kashmir valley for two consecutive years (2017 and 2018) and management during the year 2019. Observations were recorded at each calendar week from May to July by recording number of nymph/adult thrips per leaf on 20 randomly selected plants, starting from the first appearance of thrips in the field to harvest. Incidence of onion thrips in major onion growing belts of Kashmir viz., Shalimar, Tailbal and Zakura were recorded during the year 2017 to 2018. Incidence was recorded from first fortnight of May till last week of July. The leaves of infested onion plants were brought to laboratory and numbers of thrips on these leaves were counted under binocular.

The percent incidence was worked out as

$\%$ Incidence $=\frac{\begin{array}{c}\text { Number of infested } \\ \text { leaves }\end{array}}{\begin{array}{l}\text { Total Number of } \\ \text { leaves observed }\end{array}} \times 100$

The severity index of the thrips in major onion growing belts was calculated as per the scale described by Thanlass et,al., 2017

Grade 1: Scattered thrips on the leaf

Grade 2: Severe infestation of thrips on only one part of the plant

Grade 3: Severe infestation of thrips on more than one part of plant

Grade 4: Severe infestation of thrips on whole plant

Severity Index (S.I): Sum of total grade points (1- 4 Infestation grade) of the infested plant/total number of infested plants observed

For the management of thrips two locations were selected which were considered to be the hotspot for their population viz., Shalimar and Mirgund. The efficacy of different insecticides 
namely Imidacloprid 17.8 SL @ $0.5 \mathrm{ml} / \mathrm{litre}$ of water, Thiacloprid 21.7 SC @ $0.4 \mathrm{ml} /$ litre of water, Spiromesifen 22.9 SC @ 0.4 ml/litre of water and Nimbicidin 1500 ppm @ 5.0 $\mathrm{ml} /$ litre of water were tested against the thrips.

\section{Results and Discussion}

\section{Seasonal incidence}

Perusal of the data in table 1 , the mean per cent incidence of onion thrip at Shalimar ranged from 6.66 in $2^{\text {nd }}$ week of May $\left(26^{\text {th }}\right.$ week after transplanting) to 30.0 in $4^{\text {th }}$ week of July $\left(36^{\text {th }}\right.$ week after transplanting) during the years 2017-18. The population of thrips peaked from $2^{\text {nd }}$ week of June and continued till $4^{\text {th }}$ week of July. Likewise mean severity index ranged from 1.07 in $1^{\text {st }}$ week of May to 1.60 in $4^{\text {th }}$ week of July. Highest mean severity index was observed in the last weeks of June and whole of July month. The data suggest that the mean population of thrips increase as the season changes from spring to summer. Similarly the data in table 2 reveals the mean per cent incidence of onion thrip at Tailbal ranged from 10.50 in $1^{\text {st }}$ week of May $\left(27^{\text {th }}\right.$ week after transplanting) to 30.55 in $4^{\text {th }}$ week of July ( $38^{\text {th }}$ week after transplanting) during the years 2017-18. Mean severity index ranged from 1.20 in $1^{\text {st }}$ week of May to 1.51 in $3^{\text {rd }}$ week of July. Highest mean severity index was observed in June and July months. The mean population of thrips remained more or less at same level during the month of May and peaked from $1^{\text {st }}$ week of June and continued till $4^{\text {th }}$ week of July.

Perusal of the data in table 3, the mean per cent incidence of onion thrip at Zakura ranged from 6.67 in $1^{\text {st }}$ week of May $\left(23^{\text {rd }}\right.$ week after transplanting) to 25.0 in $4^{\text {th }}$ week of July ( $34^{\text {th }}$ week after transplanting) during the years 2017-18. The population of thrips peaked from $1^{\text {st }}$ week of June and continued till $4^{\text {th }}$ week of July. Similarly mean severity index ranged from 1.11 in $1^{\text {st }}$ week of May to 1.48 in $2^{\text {nd }}$ week of July. Highest mean severity index was observed in the whole of July month. The data suggest that the mean population of thrips increased in the month of June and remained almost stagnant in the month of July. These results are more or less in agreement with Kavita et al., (2017), Birhade et al., (2017), Dharmatti et al., (2013) and Ibrahim and Adesiyun (2010), who also reported that there is increase in thrips population with increase in temperature.

\section{Management of thrips with different insecticides}

During the present investigation the data revealed that thrips remained a consistent insect pest on onion at all the locations during the year 2017-18. Two locations were chosen for the management of onion thrips where they were considered a key pest.

Efficacy of different doses of various insecticides like Imidacloprid $17.8 \mathrm{SL}$, Thiacloprid 240 SC, Spiromesifen 240 SC and Neem oil was evaluated. Perusal of the data in table 4 revealed that the highest average percent mortality of 74.05 was recorded in Thiacloprid 21.7 SC followed by Spiromesifen $22.9 \mathrm{SC}$ both at the dose of $0.4 \mathrm{ml} /$ litre of water with average percent mortality of 67.32 at Shalimar. This was followed by Imidacloprid 17.8 SL @ 0.5 ml/litre of water with average percent mortality of 58.20. The lowest average percent mortality of 24.75 was observed in Nimbicidin 1500 ppm @ 5.0 $\mathrm{ml} /$ litre of water. In control where only water was used as treatment recorded average percent mortality of 1.69. The descending order of efficacy of different insecticides were Thiacloprid 240 SC, <Spiromesifen 22.9 SC, <Imidacloprid 17.8 SL and <Nimbicidin 1500 ppm. All the treatments were statistically significant different when tested at $\mathrm{p}=0.05$. 
Table.1 Seasonal incidence of thrips on onion at Shalimar during 2017 -18

\begin{tabular}{|c|c|c|c|c|}
\hline Month & Calendar Week & $\begin{array}{c}\text { Week after } \\
\text { transplanting }\end{array}$ & $\begin{array}{l}\text { * Per cent } \\
\text { Incidence }\end{array}$ & $\begin{array}{l}* \text { Severity } \\
\text { Index }\end{array}$ \\
\hline \multirow[t]{4}{*}{ May } & $1^{\text {st }}$ & 25 & 7.22 & 1.07 \\
\hline & $2^{\text {nd }}$ & 26 & 6.66 & 1.17 \\
\hline & $3^{\text {rd }}$ & 27 & 8.33 & 1.07 \\
\hline & $4^{\text {th }}$ & 28 & 9.44 & 1.24 \\
\hline \multirow[t]{4}{*}{ June } & $1^{\text {st }}$ & 29 & 11.66 & 1.25 \\
\hline & $2^{\text {nd }}$ & 30 & 13.33 & 1.26 \\
\hline & $3^{\text {rd }}$ & 31 & 13.89 & 1.39 \\
\hline & $4^{\text {th }}$ & 32 & 14.99 & 1.25 \\
\hline \multirow[t]{4}{*}{ July } & $1^{\text {st }}$ & 33 & 24.44 & 1.37 \\
\hline & $2^{\text {nd }}$ & 34 & 27.22 & 1.39 \\
\hline & $3^{\text {rd }}$ & 35 & 28.89 & 1.46 \\
\hline & $4^{\text {th }}$ & 36 & 30.00 & 1.60 \\
\hline
\end{tabular}

* Mean of two years

Table.2 Seasonal incidence of Thrips on Onion at Tailbal during 2017-18

\begin{tabular}{|c|c|c|c|c|}
\hline Month & Calendar Week & $\begin{array}{c}\text { Week after } \\
\text { transplanting }\end{array}$ & $\begin{array}{l}* \text { Per cent } \\
\text { Incidence }\end{array}$ & $\begin{array}{l}\text { * Severity } \\
\text { Index }\end{array}$ \\
\hline \multirow[t]{4}{*}{ May } & $1^{\mathrm{st}}$ & 27 & 10.50 & 1.20 \\
\hline & $2^{\text {nd }}$ & 28 & 11.11 & 1.22 \\
\hline & $3^{\text {rd }}$ & 29 & 11.67 & 1.33 \\
\hline & $4^{\text {th }}$ & 30 & 12.22 & 1.32 \\
\hline \multirow[t]{4}{*}{ June } & $1^{\mathrm{st}}$ & 31 & 17.21 & 1.28 \\
\hline & $2^{\text {nd }}$ & 32 & 18.89 & 1.25 \\
\hline & $3^{\text {rd }}$ & 33 & 20.55 & 1.27 \\
\hline & $4^{\text {th }}$ & 34 & 22.78 & 1.37 \\
\hline \multirow[t]{4}{*}{ July } & $1^{\mathrm{st}}$ & 35 & 26.10 & 1.45 \\
\hline & $2^{\text {nd }}$ & 36 & 27.76 & 1.36 \\
\hline & $3^{\text {rd }}$ & 37 & 28.89 & 1.51 \\
\hline & $4^{\text {th }}$ & 38 & 30.55 & 1.49 \\
\hline
\end{tabular}

* Mean of two years 
Table.3 Seasonal incidence of thrips on onion at Zakura during 2017-18

\begin{tabular}{|c|c|c|c|c|}
\hline Month & Calendar Week & $\begin{array}{c}\text { Week after } \\
\text { transplanting }\end{array}$ & $\begin{array}{l}\text { * Per cent } \\
\text { Incidence }\end{array}$ & $\begin{array}{l}* \text { Severity } \\
\text { Index }\end{array}$ \\
\hline \multirow[t]{4}{*}{ May } & $1^{\mathrm{st}}$ & 23 & 6.67 & 1.11 \\
\hline & $2^{\text {nd }}$ & 24 & 7.50 & 1.15 \\
\hline & $3^{\text {rd }}$ & 25 & 9.12 & 1.27 \\
\hline & $4^{\text {th }}$ & 26 & 10.00 & 1.36 \\
\hline \multirow[t]{4}{*}{ June } & $1^{\mathrm{st}}$ & 27 & 10.67 & 1.43 \\
\hline & $2^{\text {nd }}$ & 28 & 13.75 & 1.39 \\
\hline & $3^{\text {rd }}$ & 29 & 15.83 & 1.28 \\
\hline & $4^{\text {th }}$ & 30 & 17.08 & 1.35 \\
\hline \multirow[t]{4}{*}{ July } & $1^{\text {st }}$ & 31 & 21.67 & 1.36 \\
\hline & $2^{\text {nd }}$ & 32 & 22.50 & 1.48 \\
\hline & $3^{\text {rd }}$ & 33 & 22.92 & 1.47 \\
\hline & $4^{\text {th }}$ & 34 & 25.00 & 1.47 \\
\hline
\end{tabular}

* Mean of two years

Table.4 Efficacy of different insecticides against onion thrips at Shalimar during the year 2019

\begin{tabular}{|c|c|c|c|c|c|c|}
\hline \multirow[t]{2}{*}{ Treatments } & \multirow[t]{2}{*}{$\begin{array}{l}\text { Dose } \\
\mathrm{ml} / \text { litre }\end{array}$} & \multicolumn{4}{|c|}{$\begin{array}{l}\text { Corrected percent mortality } \\
\text { Days after spray }\end{array}$} & \multirow{2}{*}{$\begin{array}{l}\text { Average } \\
\text { percent } \\
\text { mortality }\end{array}$} \\
\hline & & 1 & 3 & 7 & 10 & \\
\hline $\begin{array}{l}\text { Imidacloprid } \\
\text { 17.8 SL }\end{array}$ & 0.5 & $\begin{array}{l}86.67 \\
(68.23)\end{array}$ & $\begin{array}{l}73.29 \\
(58.57)\end{array}$ & $\begin{array}{l}51.26 \\
(45.48)\end{array}$ & $\begin{array}{l}21.60 \\
(27.55)\end{array}$ & 58.20 \\
\hline $\begin{array}{l}\text { Thiacloprid } \\
\text { 21.7 SC }\end{array}$ & 0.4 & $\begin{array}{l}95.67 \\
(77.58)\end{array}$ & $\begin{array}{l}89.23 \\
(70.47)\end{array}$ & $\begin{array}{l}65.21 \\
(53.57)\end{array}$ & $\begin{array}{l}46.12 \\
(42.55)\end{array}$ & 74.05 \\
\hline $\begin{array}{l}\text { Spiromesifen } \\
22.9 \mathrm{SC}\end{array}$ & 0.4 & $\begin{array}{l}91.26 \\
(72.42)\end{array}$ & $\begin{array}{l}82.11 \\
(64.64)\end{array}$ & $\begin{array}{l}59.63 \\
(50.29)\end{array}$ & $\begin{array}{l}36.31 \\
(36.86)\end{array}$ & 67.32 \\
\hline $\begin{array}{l}\text { Nimbicidin } \\
1500 \text { ppm }\end{array}$ & 5.0 & $\begin{array}{l}38.61 \\
(38.21)\end{array}$ & $\begin{array}{l}29.68 \\
(32.84)\end{array}$ & $\begin{array}{l}23.11 \\
(28.58)\end{array}$ & $\begin{array}{l}7.61 \\
(15.93)\end{array}$ & 24.75 \\
\hline Control & Water & $\begin{array}{l}1.75 \\
(7.58)\end{array}$ & $\begin{array}{l}1.61 \\
(7.25)\end{array}$ & $\begin{array}{l}1.51 \\
(7.02)\end{array}$ & $\begin{array}{l}1.91 \\
(7.90)\end{array}$ & 1.69 \\
\hline $\mathrm{CD}(\mathrm{P}=0.05)$ & & 1.87 & 1.56 & 2.09 & 1.41 & \\
\hline
\end{tabular}


Table.5 Efficacy of different insecticides against onion thrips at Mirgund during the year 2019

\begin{tabular}{|c|c|c|c|c|c|c|}
\hline \multirow[t]{2}{*}{ Treatments } & \multirow[t]{2}{*}{$\begin{array}{l}\text { Dose } \\
\mathrm{ml} / \text { litre }\end{array}$} & \multicolumn{4}{|c|}{$\begin{array}{l}\text { Corrected percent mortality } \\
\text { Days after spray }\end{array}$} & \multirow{2}{*}{$\begin{array}{l}\text { Average } \\
\text { percent } \\
\text { mortality }\end{array}$} \\
\hline & & 1 & 3 & 7 & 10 & \\
\hline $\begin{array}{l}\text { Imidacloprid } \\
\text { 17.8 SL }\end{array}$ & 0.5 & $\begin{array}{l}90.43 \\
(71.60)\end{array}$ & $\begin{array}{l}76.21 \\
(60.49)\end{array}$ & $\begin{array}{l}60.45 \\
(50.76)\end{array}$ & $\begin{array}{l}28.54 \\
(32.12)\end{array}$ & 63.90 \\
\hline $\begin{array}{l}\text { Thiacloprid } \\
\text { 21.7 SC }\end{array}$ & 0.4 & $\begin{array}{l}92.12 \\
(73.31)\end{array}$ & $\begin{array}{l}89.32 \\
(70.55)\end{array}$ & $\begin{array}{l}70.65 \\
(56.90)\end{array}$ & $\begin{array}{l}41.87 \\
(40.11)\end{array}$ & 73.49 \\
\hline $\begin{array}{l}\text { Spiromesifen } \\
\text { 22.9 SC }\end{array}$ & 0.4 & $\begin{array}{l}89.76 \\
(70.96)\end{array}$ & $\begin{array}{l}79.85 \\
(63.00)\end{array}$ & $\begin{array}{l}64.34 \\
(53.05)\end{array}$ & $\begin{array}{l}32.79 \\
(34.75)\end{array}$ & 66.68 \\
\hline $\begin{array}{l}\text { Nimbicidin } \\
1500 \text { ppm }\end{array}$ & 5.0 & $\begin{array}{l}40.45 \\
(39.29)\end{array}$ & $\begin{array}{l}32.12 \\
(34.34)\end{array}$ & $\begin{array}{l}28.45 \\
(32.06)\end{array}$ & $\begin{array}{l}13.78 \\
(21.67)\end{array}$ & 28.70 \\
\hline Control & Water & $\begin{array}{l}1.61 \\
(7.25)\end{array}$ & $\begin{array}{l}1.95 \\
(7.98)\end{array}$ & $\begin{array}{l}1.23 \\
(6.33)\end{array}$ & $\begin{array}{l}0.76 \\
(4.97)\end{array}$ & 1.38 \\
\hline $\mathrm{CD}(\mathrm{P}=\mathbf{0 . 0 5})$ & & 1.09 & 1.98 & 1.56 & 2.58 & \\
\hline
\end{tabular}

Arc sin transformation in parenthesis
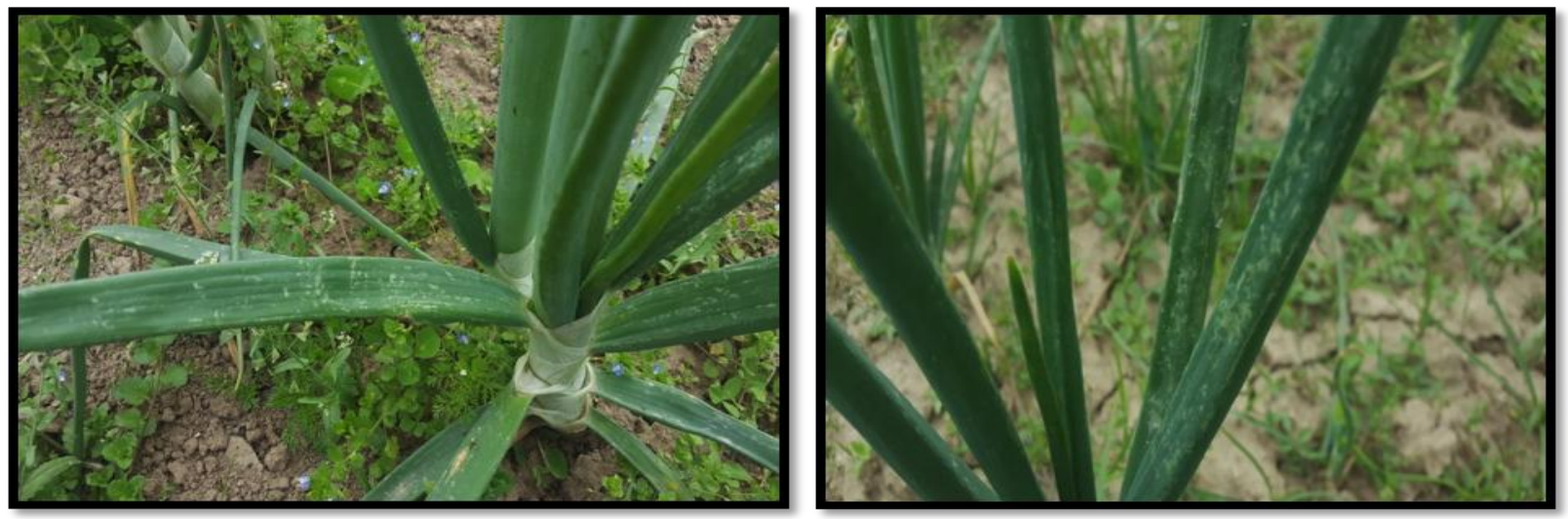

Scarring on onion leaves due to thrip feeding

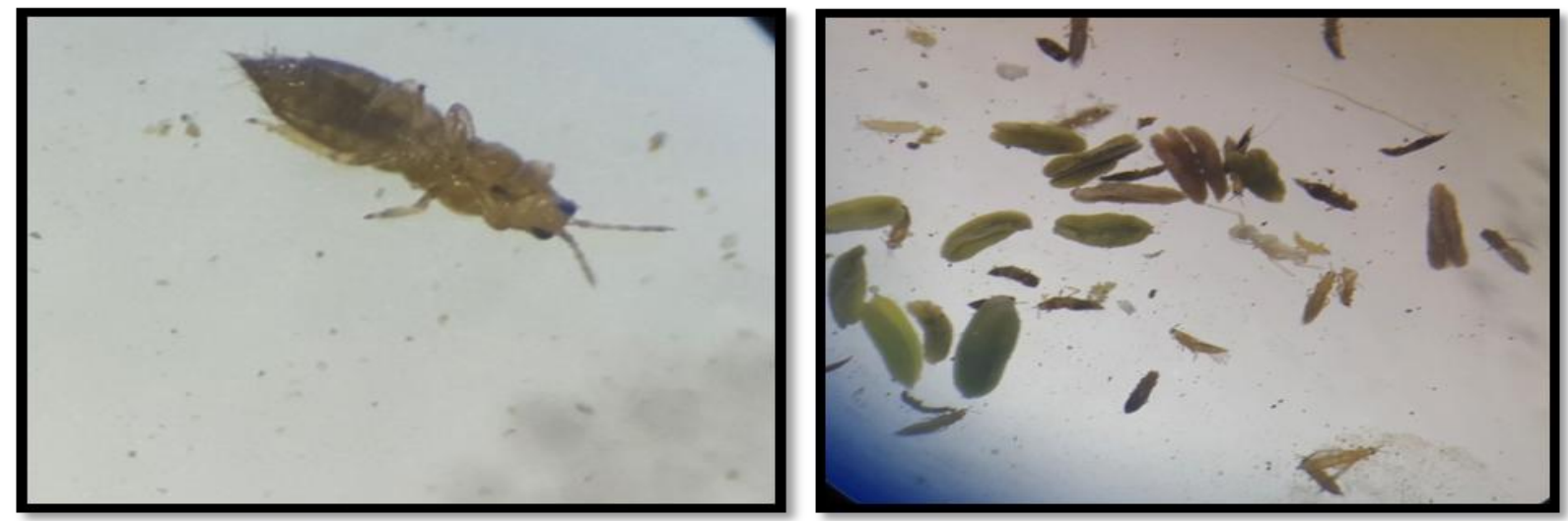

Thrips under magnification 
The data in table 5 reveal that at Mirgund the same trend was observed as that of Shalimar. The highest average percent mortality of 73.49 was recorded in Thiacloprid 21.7 SC followed by Spiromesifen 22.9 SC with average percent mortality of 66.68 , both at the dose of $0.4 \mathrm{ml} /$ litre of water. Imidacloprid 17.8SL @ $0.5 \mathrm{ml} /$ litre of water had the average percent mortality of 63.90 , followed by Nimbicidin 1500 ppm @ $5.0 \mathrm{ml} / \mathrm{litre}$ of water recorded the average percent mortality of 28.70. The descending order of efficacy of different insecticides were Thiacloprid 240 SC, <Spiromesifen 22.9 SC, <Imidacloprid 17.8 SL and <Nimbicidin $1500 \mathrm{ppm}$.

These observations are in consensus with Patel et al., 2001, Sallam and Hossney 2003 and Pokharkar et al., 2011 who also reported that newer insecticides/acaricides are effective in controlling the thrips on onion crop. All the treatments were statistically significant different when tested at $\mathrm{p}=0.05$. Therefore, from the results obtained Thiacloprid 21.7 SC @ 0.4ml/litre of water could be used for the management of onion thrips on onion crop.

\section{References}

Birhade, D.P., Kabre, G.B. and Khating, S.S. (2017). Seasonal incidence of thrips (Thrips tabaci, Lind.) on onion in Khandesh region of Maharashtra. International Journal of Plant Protection, 10 (1): 203-205

Dharmasena, C.M.D. (1998). Present status of managing leaf curl complex in the north central province of Sri-lanka. Trop. Agric. Res. and Extn., 1(2): 154-158.

Dharmatti PR, Beeraganni and Kavita M. 2013. Seasonal abundance of onion thrips, Thrips tabaci Lindeman. International Journal Plant Protection, 6(2): 428-431.

Fournier, F., Boivin, G. and Stewart, R.K. (1995). Effect of Thrips tabaci on yellow onion yields and economics thresholds for its management. J. Econ. Entomol., 88: 1401- 1407.

Ibrahim ND and Adesiyun AA. 2010. Seasonal abundance of onion thrips. Thrips tabaci L. Journal of Agricultural Sciences 2(1): 2-10.

Kavita Kumawat, B.L. Jat and Rekha Kumawat (2018). Seasonal incidence of thrips, Thrips tabaci on onion. Journal of Entomology and Zoology Studies 6(3): 1047-1049.

Nault, B.A. and Shelton, A.M. (2010). Impact of insecticide efficacy on developing action thresholds for pest management: A case study of onion thrips on onion. $J$. Econ. Entomol., 103: 1315-1326.

Patel M.G, Chavda A.J, Sisodia, D.B and Patel, J.R. 2001. Bioefficacy of new molecules in comparison to conventional insecticides against onion thrips in middle Gujarat. In: Bhardwaj S.S, Saxena R.C and Swaminathan R. eds. Proc. Conf.: Plant Protection. New horizons in the millennium, Udaipur 30: 23-25.

Pokharkar, D.S, Kale, L.K. and Pawar, D.B. 2011. Management of onion thrips, $T$. tabaci through varietal screening and newer insecticide. Journal of Agricultural Research Technology, 36(2): 237-240.

Sallam, A.A.A and Hossney, M.H. 2003. Effect of some insecticides against Thrips tabaci Lindeman and relation with yield of onion crop. Journal of Agricultural Sciences, 34(1): 99-110.

Shitole, D.M., Shankar, G. and Mithyantha, M.S. (2002). Evaluation of certain new insecticides against onion thrips (Thrips tabaci Lind.). Pestology, 26(2): 49-51.

Thanlass N, Hafeez, A. Shankar, U, Ganai, S.A. Chaand, D. Bajiya, M.R and Landol, S. 2017. Screening for resistance in rose against aphid, Macrosiphum rose and rose thrips Scirtothrips dorsalis. Journal of Entomology and Zoology Studies, 5 (6): 1960-1962 


\section{How to cite this article:}

Asma Sherwani, Peerzada Shafat Hussian, Malik Mukhtar and Shaheen Gul. 2020. Bionomics and Management of Onion Thrips Thrips tabaci (Lindeman) on Onion Grown under Kashmir Conditions. Int.J.Curr.Microbiol.App.Sci. 9(02): 2852-2859. doi: https://doi.org/10.20546/ijcmas.2020.902.324 